\section{Effect of Protease Inhibitor (S-PI) on the Growth of Various Yeasts}

\author{
Motoo AraI, Eiko TsuchiYa \\ and Sawao Murao
}

\begin{abstract}
Department of Agricultural Chemistry, College of Agriculture, University of Osaka Prefecture, Sakai, Osaka
\end{abstract}

Received January 11, 1978

An acid protease inhibitor (S-PI*) inhibited various acid proteases. In previous papers, ${ }^{1,2)}$ we reported that S-PI inhibited the growth of Rhodotorula at higher temperature, but accelerated it at lower temperature at $\mathrm{pH}$ 2.8. This paper describes the effect of S-PI on the growth of various yeasts.

Yeast cells were cultured in S-PI free and S-PI added media containing $7 \%$ glucose, $2 \%$ polypepton, $0.6 \% \mathrm{KH}_{2} \mathrm{PO}_{4}, 0.08 \% \mathrm{MgSO}_{4} \cdot 7 \mathrm{H}_{2} \mathrm{O}, 4 \mathrm{ppm} \mathrm{FeSO}_{4}$. $7 \mathrm{H}_{2} \mathrm{O}, 4 \mathrm{ppm} \mathrm{MnSO}_{4} \cdot 6 \mathrm{H}_{2} \mathrm{O}, 2 \mathrm{ppm}$ thiamine $\mathrm{HCl}$ and $0.1 \%$ yeast extract at $25^{\circ} \mathrm{C}$ for $96 \mathrm{hr}$. The concentration of S-PI in the medium was $60 \mathrm{ppm}$. The growth of yeast was followed by $O D$ at $660 \mathrm{~nm}$. Fifty nine strains of yeasts were used in this experiment. These strains were stocked cultures in our laboratory.

Figure 1 shows the effect of S-PI on the growth of 4 strains of yeasts. The growth acceleration by S-PI was observed evidently. But the optimum $\mathrm{pHs}$ for the growth acceleration were different from each other. The strains whose growth were accelerated by S-PI are listed in Table I. It is evident that S-PI was effective on the acceleration of growth of various yeasts. On the other hand, 7 strains of Debaryomyces, 10 strains of Saccharomyces, 1 strain of Lipomyces etc. were not effective with S-PI. But taking into consideration that acceleration of growth, caused by S-PI, was related to the cultivation temperature, ${ }^{1)}$ S-PI might be effective to these strains in some conditions.

The extracellular acid protease production of various yeasts was investigated by Murao et al..$^{\text {. }}$ and they found that Rhodotorula glutinis $\mathrm{K}-24$ produced a large amount of extracellular acid protease when the yeast grew below $\mathrm{pH} 4.5$, and maximum formation occured in the cultivation of initial $\mathrm{pH} 2.8$. The physiological changes induced by S-PI addition were observed under the same conditions as the maximum extracellular acid protease production. Thus there seemed to exist some relation between the inhibition of the extracellular acid protease and the physiological changes of the cells. However, in this experiment, S-PI accelerated the cell growth of various yeasts independently of their extracellular protease production. Therefore, it might be reasonable to conclude that physiological changes induced by S-PI was not directly related to the extracellular acid protease production. On the other hand, the intracellular acid proteases play an important role in the yeast growth. ${ }^{4 \sim 5)}$ The physiological changes of yeast caused by S-PI might be related to the intracellular acid protease and this problem is now under investigation and will be reported elsewhere.

\section{REFERENCES}

1) S. Murao, M. Arai, K. Nakahara and M. Tsuchiya, Nippon Nôgeikagaku Kaishi, 49, 585 (1975).

2) M. Arai, M. Tsuchiya and S. Murao, ibid, 51, 643 (1977).

3) K. Kamada, S. Ogura, K. Oda and S. Murao, ibid., 46, 171 (1972).

4) E. Cabib and R. Ulane, Biochem. Biophys. Res. Commun., 50, 186 (1973).

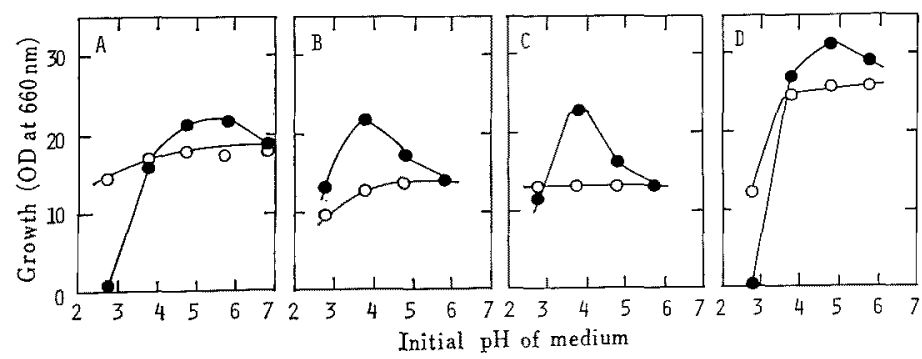

Fig. 1. Effect of S-PI on Growth of Various Yeasts.

Yeast cells were grown in S-PI free and S-PI added medium at $25^{\circ} \mathrm{C}$ for $96 \mathrm{hr}$.

A, Candida japonica IFO 1119; B, Candida salmonicola AJ 4755; C, Saccharomyces fermentati

IAM $4771 ;$ D, Cryptococcus terreus IFO 0727 . O, S-PI free medium; $\bullet$, S-PI added medium.

* S-PI is the same to Acetyl Pepstatin reported by Aoyagi et al. ${ }^{\mathrm{e}}$ 
Table I. Effect of S-PI on the Growth of Various Yeasts

The yeast was cultured in S-PI free and S-PI added media at $25^{\circ} \mathrm{C}$ for $96 \mathrm{hr}$. And then the growth of yeast in the both media were compared. The productibility of extracellular acid protease by yeast are listed for reference.

\begin{tabular}{|c|c|c|c|c|c|c|}
\hline \multirow{3}{*}{ Strain } & \multicolumn{5}{|c|}{ Growth acceleration caused by S-PI } & \multirow{3}{*}{$\begin{array}{c}\text { Acid } \\
\text { protease } \\
\text { production }^{3}\end{array}$} \\
\hline & \multicolumn{5}{|c|}{ Initial $\mathrm{pH}$ of medium } & \\
\hline & 2.8 & 3.8 & 4.8 & 5.8 & 6.8 & \\
\hline Encomycopsis fibliger IFO 0104 & + & ++ & - & - & - & yes \\
\hline Saccharomyces fermentati IAM 4771 & - & ++ & + & - & - & no \\
\hline Hansenula dimennae NRRL YB-3239 & - & - & ++ & + & - & no \\
\hline Hansenula calfornica NRRL Y-1680 & - & + & - & - & - & no \\
\hline Cryptococcus neoformans IFO 0699 & - & - & + & + & + & no \\
\hline Cryptococcus terrueus IFO 0727 & - & - & ++ & + & - & no \\
\hline Candida humicola IFO 0753 & - & - & - & + & - & no \\
\hline Candida zeylanoides ATCC 7351 & - & + & ++ & - & - & no \\
\hline Candida salmonicola AJ 4755 & + & ++ & + & - & - & no \\
\hline Candida japonica IFO 1119 & - & - & ++ & ++ & - & no \\
\hline Tricosporon penicillatum AJ 5106 & + & $+t$ & + & - & - & no \\
\hline Tricosporon fermentaus IFO 1199 & - & - & + & + & - & no \\
\hline Rhodotorula peneaus IFO 0930 & - & + & + & + & - & no \\
\hline Rhodotorula rubra IFO 0832 & - & ++ & + & - & - & yes \\
\hline Rhodotorula glutinis $\mathbf{K}-24$ & ++ & + & - & - & - & yes \\
\hline Rhodosporidium diobovatum AJ 14179 & - & - & ++ & + & - & \\
\hline Rhodosporidium spherocarpum AJ 14147 & - & + & + & - & - & \\
\hline
\end{tabular}

5) H. Holtzer, T. Katsunuma, E. G. Schött, A. R. Fergusson, A. Hasilik and H. Betz, Adv. Enzyme Regul., 11, 53 (1973).
6) T. Aoyagi, Y. Yagisawa, M. Kumagai, M. Hamada, H. Morishima, T. Takeuchi and H. Umezawa, J. Antibiot., 26.539 (1973). 